\title{
SOCIAL BUSINESS: GAINING STEAM FROM THEORY TO PRACTICE
}

\author{
ATHANA PRIESTLY VEKIMA NJIE* \\ Department of Administrative Techniques, Higher Technical Teachers' Training College Kumba, University of Buea, Cameroon. \\ Email: vekima@yahoo.co.uk
}

Received: 19 August, 2021, Revised and Accepted: 11 October , 2021

\begin{abstract}
The world is faced with a multitude of pressing problems and needs such as hunger, poverty, disease, poor health care, homelessness, pollution, adverse climate conditions, and other environmental hazards, just to name a few. Volunteer work, charities, and donations and of course the traditional profit-making businesses with all the elegant economic theories surrounding them have not been able address these ills which are a serious plaque to the society. In a bid to satisfactorily reduce or put an end to these societal hazards, Muhammad Yunus, the 2006 Nobel Peace Prize Winner and the practical genius who pioneered microcredit with his Grameen Bank, has initiated what is today known as social business. Social business is a new kind of business, not for profits, that is dedicated to solving a particular social, economic, or environmental problem that has plagued mankind since time immemorial. The whole idea about social business is to improve the lives of people by harnessing the energy of profit making to the objectives of fulfilling basic human needs. The resounding success stories of the Grameen Bank, the very first social business created by Muhammad Yunus has paved the way for other organizations to follow suit. This paper has demonstrated how social business has moved from a mere theory to a practice undertaken by several organizations that is transforming lives and having the potential to redeem the failed promise of the free-market enterprise.
\end{abstract}

Keywords: Social business, Not for profit, Humanity, Pressing needs, Muhammad Yunus.

(C) 2021 The Authors. Published by Innovare Academic Sciences Pvt Ltd. This is an open access article under the CC BY license (http://creativecommons.org/ licenses/by/4.0/) DOI: http://dx.doi.org/10.22159/ijss.2021v9i6.42919. Journal homepage: https://innovareacademics.in/journals/index.php/ijss

\section{INTRODUCTION}

The poverty and sufferings of the people of Jobra in Bangladesh who had gotten themselves entrapped in debts to money lenders and only revolving around the vicious circle of poverty, forced Muhammad Yunus to seek ways to help them out. He developed the concept of the Grameen bank (Village Bank) which was dedicated to serving the poor in that community, as a means of fighting poverty. The Grameen Bank was created on the premise of encouraging entrepreneurship and selfreliance among the poor people of Bangladesh, not dependence. Today, the Grameen Bank is serving every single village in Bangladesh and counts more than 8 million borrowers. Its impact has helped to alleviate poverty in Bangladesh significantly [1]. This was the very first social business and is now branching in new locations around the world and in diverse areas of mankind's most pressing needs.

In his book "Building Social Business," Yunus [2] explains that social business is a visionary new dimension for capitalism that targets business opportunities neglected by traditional profit-maximizing companies and reinvest any profits made, without any reward to shareholders. The big picture is to harness the energy of profit making to the objective of fulfilling human needs.

To Yunus [3], poverty is artificial, external imposition on a person and since it is external, it can be removed. Therefore, a poverty-free world can be created through social business.

The ultimate difference between the traditional business and social business is that traditional business is dedicated to personal gain, with the objective to maximize profits for its owners, with little or no consideration for others. In social business, everything is for the benefit of others and nothing for its owners, except for the pleasure of serving humanity. It is in fact a selfless business whose purpose is to bring an end to a social problem. The successes registered by the Grameen Bank in alleviating poverty have ignited the spread of more social businesses both in Bangladesh and abroad.

The aim of this paper is to demonstrate using practical examples that social business has moved from a mere concept developed by Muhammad Yunus to a practical reality of transforming lives and endowed with many more potentials to redeem the failed promise of the free-market enterprise. This paper identifies a handful of organizations practicing social business and to what extent they impact the society in alleviating poverty.

\section{THE PRINCIPLES OF SOCIAL BUSINESS}

A social business is a new kind of business, quite distinct from neither a traditional profit-maximizing business (which describes practically all private companies in the world today) nor a not-for-profit organization (which relies on charitable or philanthropic donations). It is also quite different from some other frequently used terms, such as "Social Enterprise," "Social Entrepreneurship," or "Socially Responsible Business," which generally describe varieties of profit-maximizing companies. The goal of social business is to solve a social problem using business methods, including the creation and sales of goods and services [4]. It strives fundamentally to bring about change in the architecture of our capitalist economy by bringing it closer to a complete and satisfactory framework, freeing it from the basic flaws which lead to poverty and other social and environmental ills. The concept of social business is opposed to the emptiness of traditional economic concepts which have been unable to resolve the most pressing needs of mankind.

Hans Reitz, director of the Grameen Creative Lab in Germany, who is an ally to Muhammad Yunus formulated the seven principles of social business in 2010 [5] which were later reiterated by Gabriel Kabanda in 2019 [6], bringing out its principal characteristics as follows:

1) The business objective is to overcome poverty, or one or more problems (such as education, health, technology access, and the environment) that threaten people and society not to maximize profit.

2) The company will attain financial and economic sustainability.

3) Investors get back only their investment amount. No dividend is given beyond the return of original investment.

4) When the investment amount is paid back, profit stays with the company for expansion and improvement.

5) The company will be environmentally conscious.

6) The workforce gets market wage with better-than-standard working conditions. 
7) Do it will joy!

These seven principles of social business are the core of social business.

\section{POTENTIALS OF SOCIAL BUSINESS AS A TOOL TO FIGHT AGAINST POVERTY}

As a remedy to the failures of the free-market enterprise to eradicate poverty in the world, social business has been proposed as a new response adapted to poverty diminution since it offers viable solutions (such as income from activity must cover capital investment and operating expenses and profits are dedicated for reinvestment). Notwithstanding, Perron [7] reiterates that deadlines set for achieving Millennium Development Goals that will effectively reduce poverty are tight. This suggests that there is urgent need to spread social business action across the universe. Again, investors in social business must not expect return on capital. However, we are convinced that such investors exist and that the possibilities are numerous [7]. Social business can strive in many different areas of societal life to alleviate poverty. There are many areas in which social business is excelling already and has a bright future in many others. Let us now have a look at some of these potential areas where this new kind of business can serve humanity's most pressing needs better:

\section{Employment}

Creating jobs are an attractive area for social business, especially in locations of disadvantaged people. In line with the fact that the investment decision made by a social business is rather based on a social cause and not on profit potentials, it can reinvest in projects where the return on investment is near zero. Furthermore, since profit made in social business is ploughed back into the investment, this suggests sustainability of the business and in the process opens up job opportunities for many people.

\section{Health care}

In many countries around the globe, public delivery of health care is inefficient and is often met with failure to reach the neediest. Health care is a real challenge, especially to the poor. Since social business targets solving a social problem using business methods, it has the potential to keep people healthy by concentrating on activities related to disease prevention and offering diagnostic and health check-up services. Several other segments of health care appropriate for building successful social business include nutrition, water, health insurance, health education and training, eye care, mother and child care, and diagnostic services.

\section{Technology}

Social business is a way of putting today's most powerful technologies to work. The world today is surrounded by amazing powerful technologies, which are yet growing fast and becoming more powerful by the day. Most technology is owned and controlled by profit making businesses, which are used to make more profit. However, technology is an asset that can be used in different ways to earn different objectives. This suggests that social business can as well use technologies in its pursuits in ending poverty, disease, malnutrition, and any other dilemma faced by mankind.

\section{Stock markets}

Social business will eventually need to have its own stock market to facilitate investment by its owners. Only social businesses will be listed in this social stock market and investors will know right from the beginning that they will never receive dividends from the business. Their motivation will be to enjoy the pride and pleasure of helping to solve different social problems.

\section{Banking}

The whole concept about social business began through the use of banking as a means of fighting poverty. Muhammad Yunus founded the Grameen Bank in Jobra - Bangladesh that was dedicated to serving the poor in that community. Today, the Grameen Bank is serving every single village in Bangladesh and counts about 8 million borrowers. Grameen Bank is in the business of encouraging entrepreneurship and self-reliance among people of Bangladesh - not dependence. Its impact has helped to alleviate poverty in Bangladesh significantly. The Grameen Bank is now branching in new locations around the world. For example, Grameen America, which is similarly spreading to others, states within the US. Grameen America [8] is registering enormous successes, demonstrating that, even in the richest countries in the world, with the most sophisticated banking system, there is a need for banks dedicated to serving the unserved and underserved millions.

\section{SUCCESS STORIES REGISTERED BY SOCIAL BUSINESSES}

"If we can imagine something, there is a good chance that it will happen. If we don't imagine it, there's almost no chance of it happening" says Yunus in [9]. After the Grameen Bank registered enormous successes in alleviating poverty in Bangladesh, Muhammad Yunus' social business model has become an attraction for world-renowned multinational companies to partner with him or create separate social businesses. They follow the basic principles of self-sustaining and non-dividend sharing by owners beyond the return of the original amount invested. The company's success is judged by the number of lives changed rather than the amount of profits generated. Large corporations are finally feeling the pressure to do better for the societies they serve as observed by Saskia Bruysten, CEO and Co-Founder at Yunus Social Business [10]. Donations are turned into investments in sustainable social businesses that provide employment, education, health care, safe water, and clean energy to over 9 million people worldwide. The idea is to harness the power of business to end poverty [11]. Grameen grew from a bank into several enterprises, each dedicated to serving poor rural communities in Bangladesh. Today, social businesses are scattered all over the universe and are recording positive change in the lives of people.

Table 1 outlines organizations which have ventured into social business; some in partnership with Muhammad Yunus' Grameen companies

Tables 1: Organizations practicing social business and the impact they create to alleviate poverty

\begin{tabular}{|c|c|c|}
\hline Organization & Social business activity & Impact \\
\hline Grameen Bank (Bangladesh) & $\begin{array}{l}\text { Offering banking services to the poorest people of } \\
\text { Bangladesh. Grameen Bank is in the business of } \\
\text { encouraging entrepreneurship and self-reliance } \\
\text { among people of Bangladesh - not dependence. } \\
\text { Grameen Bank is financially self-reliant and all its } \\
\text { funds come from deposits, mostly from the borrowers } \\
\text { themselves, who are required to save a little bit every } \\
\text { week. They had a collective savings balance of over } \\
\text { half a billion dollars } 4 \text { years after it was created. }\end{array}$ & $\begin{array}{l}\text { Totaling } 8 \text { million borrowers, Grameen bank lends out } \\
\text { over } 100 \text { million dollars a month in collateral-free loans } \\
\text { averaging about } 200 \text { dollars. Grameen bank also lends } \\
\text { money to beggars who carryout little business activities } \\
\text { such as selling toys, household items, and food stuffs } \\
\text { from door to door alongside with begging. Over } 100,000 \\
\text { beggars are engaged in this program and over } 18,000 \text { of } \\
\text { the have quit begging within the } 4^{\text {th }} \text { year of the program. } \\
\text { The bank also encourages children of borrowers to go to } \\
\text { school, offering affordable loans for them to pursue their } \\
\text { education. Over } 50,000 \text { students are currently pursuing } \\
\text { their education in medical schools, engineering schools, } \\
\text { and universities with financing from Grameen Bank }\end{array}$ \\
\hline
\end{tabular}


Tables 1: (Continued)

\begin{tabular}{|c|c|}
\hline Organization & Social business activity \\
\hline $\begin{array}{l}\text { Grameen-Danone } \\
\text { (French Dairy Company) }\end{array}$ & $\begin{array}{l}\text { Produces highly nutritive and delicious yogurt for } \\
\text { children. Fortified with all micronutrients that are } \\
\text { missing in children ordinary diet such as iron, iodine, } \\
\text { zinc, etc. }\end{array}$ \\
\hline Grameen-Veolia & Produces safe drinking water to the villages of \\
\hline (Mega French Water Company) & Bangladesh \\
\hline BASF-Grameen (German & Produces chemically treated mosquito nets in \\
\hline Company) & Bangladesh \\
\hline Intel Corporation & $\begin{array}{l}\text { Use information and communication technology to } \\
\text { help reduce poverty in rural areas }\end{array}$ \\
\hline
\end{tabular}

Adidas Produces affordable shoes for lowest income people

\section{Impact}

Reduce malnutrition among children in Bangladesh by selling the yogurt at very low prices, affordable by the poorest people

Reduces arsenic contamination of drinking water, promoting good health among the poor [12] Providing protection from mosquito-borne diseases such as malaria. Sold at give away prices such that the poorest in Bangladesh communities can afford

Creating exciting new technologies that can bring the most advanced healthcare concepts within reach of poor villagers and then create a cadre of small scale entrepreneurs who will deliver these vital services in an economically sustainable fashion. Examples are mobile money transfers, call boxes, etc.

Neither children nor adults can go without shoes in the developing world, practically reducing parasitic diseases that can be transmitted through walking bare feet. This is a health benefit

Otto GMBH-Grameen (German Global leader in mail-order business, to produce Company) textile and garments in south Asian countries and export to developed countries

Employ economically marginal people, female single parents and disabled persons. Profits are used to improve the quality of life for employees, their children and the poor of the neighborhood

So far, they have provided food for more than 2.3 million people at a very low cost in Costa Rica and Nicaragua.

Nutrivida is a social business committed to

NUTRIVIDA-FIFCO

(Costa Rica) eradicating "'hidden hunger" in the world by selling
Global Health at Medtronic Labs highly nutritional food products at an affordable price

Medtronic is running a social business which helps some of the most vulnerable patients access vital health care across West Africa and East Africa and South Asia

Provide telecommunication facilities to people

Grameen Telecom and Grameen Phone throughout Bangladesh

Provides solar home system solutions

Energy, 1

Energy, 1995) in Bangladesh

Grameen Kalyan (Grameen Well-being, 1997)

Grameen Fisheries and Livestock Foundation (1986)

Exists to provide good quality, affordable health care for Grameen Bank borrowers and other villagers

Administer fish ponds in northern and western Bangladesh

Provide education to the children of borrowers of Grameen Bank

Education (1997)

Textile company created to revive and modernize the Enterprise) (1996) traditional Bangladeshi handloom manufacturing international markets and are creating more wealth for cotton fabrics and garments

The social business is now financially independent from the parent company FIFCO

They are expanding access to healthcare for people living with non-communicable diseases. Over 20 million people are benefiting from their services

Launched in 1996 and quickly expanded to whole country. In 2009, Grameen Phone had become the largest tax-paying-company in Bangladesh, with over 25 million subscribers. More than 400,000 telephone ladies (jobs) were created through this program

Provides about 14,000 solar home systems per month and by 2010 had installed more than half a million of these systems and also 50,000 biogas plants in operation Operates 54 clinics and offers a health insurance program providing basic healthcare to families for the equivalent of around 2 US dollars per year per family By the end of 2009 , more than 3,000 poor people in Bangladesh were employed to work in these fish ponds that could produce at least 2000 tons of fish per year Awards scholarships to poor students, more than 2500 students already benefitted as of 2003. The scheme is continuing their communities and a better life for themselves
Grameen Uddog (Grameen Textile company created to revive and modernize the Local weavers have been brought to the limelight of

Sources: Unusual Pioneers [11]; Yunus [13]

and others standing on their own. The impact they create to alleviate poverty and bring about positive change in the lives of people is a measure of the worth of social business in our society today.

\section{CONCLUSION}

The economic theory taught in schools must be reoriented to take into account the multidimensional reality of human nature to make the world a better place for everyone to live in happily. Meanwhile, the new economic lessons in schools should clearly distinguish between the two kinds of businesses that exist traditional money making businesses (which have been unable to transform peoples' lives and alleviate poverty) and social business (which seem unprofitable to shareholders because they do not plough back profit), but bring about significant change to the society. The evidence of the power of social business in alleviating poverty and offering mankind's most pressing needs is quite visible through its works. Governments have an important role to play in promoting social businesses because it will help them in meeting up with their populations' most pressing needs. Legislation needs to be passed to recognize legally social businesses and create regulatory bodies to ensure transparency, integrity, and honesty in this sector. Tax incentives for such businesses will be of good as well.

\section{REFERENCES}

1. Yunus M. Beginning with a tiny step. In: Building Social Business: The New Kind of Capitalism that Serves Humanity's Most Pressing Needs. 
New York: Public Affairs; 2010. p. 8-10.

2. Yunus M. Social business as a new form of capitalism. In: Building Social Business: The New Kind of Capitalism that Serves Humanity's Most Pressing Needs. New York: Public Affairs; 2010. p. 24

3. Yunus M. The end of poverty. In: Building Social Business: The New Kind of Capitalism that Serves Humanity's Most Pressing Needs. New York: Public Affairs; 2010. p. 199.

4. Yunus M. What social business is and is not. In: Building Social Business: The New Kind of Capitalism that Serves Humanity's Most Pressing Needs. New York: Public Affairs; 2010. p. 4.

5. Yunus M. Why social business? In: Building Social Business: The New Kind of Capitalism that Serves Humanity's Most Pressing Needs. New York: Public Affairs; 2010. p. 3.

6. Kabanda G. In: Yunus M, editor. Building Social Business: The New Kind of Capitalism That Serves Humanity's Most Pressing Needs. Vol. 4. New York, United States: Perseus Books Group; 2019. p. 36-43. Available from: http://www.crsdindia.com/ajmecs.html

7. Perron JL. Promoting and developing social business: A French perspective [typo dans VF]. J Soc Bus 2011;1:1-12.

8. Yunus M. Social business-from dream to reality. In: Building Social Business: The New Kind of Capitalism that Serves Humanity's Most Pressing Needs. New York: Public Affairs; 2010. p. 11.

9. Yunus M. A World of Three Zeros: The New Economics of Zero Poverty, Zero Unemployment, and Zero Net Carbon Emissions. New York: Public Affairs; 2017.

10. Yunus Social Business Blog. Education for a World of Three Zeroes; 2021. Available from: https://www.yunussb.com [Last accessed on 2021 Jun 24].

11. Unusual Pioneers. Yunus Social Business and the Schwab Foundation for Social Entrepreneurship Partner to Support Social Intrapreneurs in their Quest to Transform Corporations; 2021. Available from: https:// www.yunussb.com [Last accessed on 2021 Jun 24].

12. Blanchet T. Grameen Veolia Water Ltd.: Assessment of a Social Business Project with an Anthropologist Perspective; 2011.

13. Yunus M. Building Social Business: The New Kind of Capitalism that Serves Humanity’s most Pressing Needs. New York: Public Affairs; 2010. 